DOI 10.18551/rjoas.2019-05.10

\title{
CONSUMER CHARACTERISTICS RELATED TO WILLINGNESS TO PAY FOR ORGANIC RICE
}

\author{
Zamrodah Yuhanin* \\ Department of Agribusiness, Faculty of Agriculture, University of Islamic Blitar, Blitar \& \\ Department of Agribusiness, Faculty of Agriculture, University of Brawijaya, Malang, \\ Indonesia
}

Koestiono Djoko, Setiawan Budi, Syafrial

Faculty of Agriculture, University of Brawijaya, Malang, Indonesia

*E-mail: yuhaninzamrodah@yahoo.com

\begin{abstract}
Rice is one of the staple foods which are one of the great potentials to be produced in premium. Premium rice is rice that is free of artificial chemicals which can endanger the health of consumers so that premium rice is healthy for consumption. There is a new fact that the demand for organic rice products is more increasing. The aims of this study are to identify the preferred type of organic rice in the market and to identify the characteristics of its consumers. The analysis method uses descriptive analysis and to calculate the value of willingness to pay (WTP) consumer using Contingent Valuation Method (CVM). The results show the most demand for organic rice is $\mathrm{N} 790$ and riceya. The type of consumer of organic rice is entrepreneur and government employees. Finally, the willingness to pay for organic rice is based on the reason for the positive impact on the environment and health.
\end{abstract}

\section{KEY WORDS}

Willingness to pay, organic rice, consumers, characteristics, health.

Increasing population and along with the times have also led to an increase in demand for food products, one of which is rice. Rice is a staple food that is needed by all people to meet their calorie needs. For Indonesian people, rice is known as the main food ingredient which is not easily replaced by other food ingredients. In line with the increasingly high standard of human life and the increasing population of the world, the protection of land resources is becoming a concern. Efforts to increase productivity are finally faced with the problem of how to limit environmental damage and further resources through an environmentally friendly organic farming system. People are beginning to realize the dangers of modern farming systems with the use of chemical fertilizers so that they are now turning to organic farming systems (Verma et al., 2011). The transition of people to a healthier lifestyle is increasing along with the increase in demand for organic products.

Public awareness of health is more tend to consume organic rice. Organic rice, which is rice that does not contain harmful chemicals (Takei, N. 2019; Pantoja, et al., 2016). The use of chemical pesticides and chemical fertilizers is replaced by the use of organic pesticides and fertilizers, so organic farming no longer relies on chemical pesticides alone but uses biological pesticides so it is safer to consume. Organic food products have many advantages compared to inorganic food products namely environmentally friendly and do not endanger the health of consumers (Novandari, 2011). However, in obtaining organic rice there are still some obstacles, namely the lack of information available to consumers regarding organic food and its limited supply also causes organic food products not to develop evenly and the price of organic rice is more expensive than non-organic rice (Jukes \& Anderson Stout, 1977). Nevertheless, the potential demand for organic food products, one of which is organic rice in Indonesia, has increased considerably in recent years. Based on the institute's strategic planning study in Garretson et al. (2002) found that quality products will be more profitable and have the largest market share. 
The willingness or willingness to pay according to Fauzi (2006) can be defined as the amount that a consumer can pay to obtain a good or service. Sure (1997) defines the willingness of consumers to pay (Willingness to Pay) as the amount of money someone wants to give to obtain an improvement in environmental conditions. Thus, willingness to pay is the maximum value that consumers want to pay to get a product (Balogh et al., 2016) or can also be interpreted as the willingness of consumers to pay more for the premium price of a product or service. This connotation takes into account the degree of sacrifice for what consumers have acquired (Shin et al., 2017). Purchasing decision theory according to Engel (1995) says that the buying decision making process refers to consistent and prudent actions taken to meet needs. There are various types of organic rice sold on the market. This indicates the existence of competition in marketing organic rice. Producers are required to determine the right marketing strategy to get customer loyalty. One of the ways is to analyze the value of willingness to be paid or willingness to pay (WTP) by consumers to organic rice. Consumers who consume organic rice certainly have different characteristics. Thus the clustering of WTP values based on consumer characteristics can help in determining the market segment. From the description above, it is obtained the purpose of this study to identify organic rice which circulating in the market and identify the characteristics of consumers who purchase organic rice using descriptive analysis, calculating the willingness to pay (WTP) of consumers by using the Contingent Valuation Method (CVM) method.

\section{METHODS OF RESEARCH}

This research was conducted in a modern market that sells organic rice in the city of Malang. Site selection is done intentionally, because in the city of Malang has different characteristics of society, either at the level of education, employment and income. In this study, 80 respondents were chosen. Data analysis used is descriptive analysis to describe the characteristics of organic rice consumers and quantitative analysis using willingness to pay (WTP) to determine the value that consumers want to pay. WTP calculations for goods that have market prices do not have a special calculation method. Thus, several steps are used to find the best results, so there are several steps that are the same as the CVM method as revealed by Hanlay and Spash (1993) in Simanjutak (2006).

\section{RESULTS OF STUDY}

Organic Rice which Circulating in Malang City Market is one of the big cities located in East Java. Malang City has a diversity of population starting from the level of education, employment and income. In recent years, a healthier lifestyle has become increasingly popular. One of the ways is to choose organic processed foods, including rice. Organic rice is rice that is free from preservatives and bleach, thus producing rice that has a softer texture and a more natural aroma. In the city of Malang there are also various modern markets that sell a variety of organic rice, such as Hypermarket, Mall Olympic Garden, Avia, Carrefour and outlets that sell organic rice. As for some organic rice sold in the modern market, among others, the brand of riceya, N790, coklat organic, pandan wangi and mentik wangi delangu. From each organic rice brands have different prices as presented in Table 1.

Based on Table 1 the brand of organic rice that has the highest price of one $\mathrm{kg}$, which is $25.000 \mathrm{IDR} / \mathrm{Kg}, \mathrm{N} 790$ brand organic rice and mentik wangi delangu brand has a selling price of $20.000 \mathrm{IDR} / \mathrm{kg}$, while the organic rice of the coklat organic brand and the pandan wangi brand has the lowest price among the prices of other organic rice, which is 17.000 IDR. High and low prices on organic rice will also affect consumers in buying organic rice.This is in accordance with Castro\&Knoke (2015) opinion in his research which states that the high and low prices of organic rice will affect consumers in making decisions. While according to Liang (2016) relation to low-price scenarios, consumers required more confidence to purchase higher-priced goods, meaning that the relational embeddedness in a channel exerted more influence on purchase intentions. By contrast, compared to the highprice scenarios, consumers tended to choose lower-priced goods based on personal 
preferences, e.g., making the purchase decision based on trust in the organic label and attitudes toward organic food.

Table 1 - List of Organic Rice Prices

\begin{tabular}{cc}
\hline Organic Rice Brand & Price $(\mathrm{Kg})$ \\
\hline Riceya & 25.000 \\
N 790 & 20.000 \\
Coklat organic & 17.000 \\
Pandan Wangi & 17.000 \\
Mentik Wangi Delangu & 20.000 \\
\hline
\end{tabular}

Source: Primary Data, 2018.

Consumer Characteristics. The characteristics of respondents can be an illustration in identifying consumer behavior. Respondents in this study can be described by their characteristics, such as gender, age, marital status, education, occupation, income, consumption level. In the research conducted by Levy and Maheswaran (1990) it was found that there were differences in the behavior of the types of respondents male and female. These differences include the process of receiving information, differences in attitude so that there is an influence on behavior in making purchases.

Table 2 - Characteristics of Respondents by Gender

\begin{tabular}{ccc}
\hline Gender Person & Number (Person) & Distribution (\%) \\
\hline Male & 30 & 37.5 \\
Female & 50 & 62.5 \\
\hline Total & 80 & 100
\end{tabular}

Source: Primary Data, 2018.

Respondents of organic rice in Malang city of male gender amounted to 30 people or $37.5 \%$, while female respondents were 50 people or $62.5 \%$. From the data, it can be seen that the difference between male and female respondents is about $25 \%$. Here it is considered that women tend to influence decisions in the purchase of organic rice. Ginigaddara et al, 2017 also proved that the awareness and the purchasing decision making for organic foods are higher among females than males.

Characteristics of organic rice respondents in Malang City are spread based on several age levels. According to Peter and Olson (1999) states that the characteristics attached to each individual is different and may affect the behavior patterns in determining the purchase.

Table 3 - Characteristics of Respondents by Age

\begin{tabular}{ccc}
\hline Age (Year) & Number (Person) & Distribution (\%) \\
\hline$<30$ & 20 & 25 \\
$30-39$ & 35 & 43.75 \\
$40-49$ & 15 & 18.75 \\
$50-59$ & 10 & 12.5 \\
\hline Total & 80 & 100
\end{tabular}

Source: Primary Data, 2018.

Based on the table above, 20 people under 30 years old, 30-39 years old as many as 35 people, 40-49 years old as many as 15 people and 50-59 years old as many as 10 people, with different ages will be able to influence in making decisions to buy organic rice.

Marital status is considered important as a category of characteristics of respondents assessed. In Peter and Olson (1999), it is stated that an individual's marital status can influence behavior patterns in determining purchasing decisions, this is due to the influence of the family and the environment that determines the behavior of individuals as consumers. 
Table 4 - Characteristics of Respondents by Marriage Status

\begin{tabular}{ccc}
\hline Marriage Status (Year) & Number (Person) & Distribution (\%) \\
\hline Not Married & 25 & 31.25 \\
Married & 55 & 68.75 \\
\hline Total & 80 & 100 \\
\hline
\end{tabular}

Source: Primary Data, 2018.

According to the data in the table above, the respondents in this study were 25 unmarried people and 55 married people. Organic rice consumers are very diverse both those who are married or not married. Education is one characteristic that is good enough to describe the identity of respondents.

Table 5 - Characteristics of Respondents according to Level of Education

\begin{tabular}{ccc}
\hline Level of Education & Number (Person) & Distribution (\%) \\
\hline Senior High School & 20 & 25 \\
Diploma & 15 & 18.75 \\
Bachelor & 45 & 56.25 \\
\hline Total & 80 & 100 \\
\hline
\end{tabular}

Source: Primary Data, 2018.

Be aware of the table above there are some respondents who only have the last education of Senior High School and Diploma, but most respondents are educated, the last education of Bachelor there were as many as 45 people or $56.25 \%$. With the existence of differences in the last educational range carried by the respondents, it will also influence the decision to buy organic rice.

Distribution of respondents based on work, then there are several classes of work, i.e. entrepreneurs, civil servants, private employees and students/ college students.

Table 6 - Characteristics of Respondents by Job Type

\begin{tabular}{ccc}
\hline Type of Job & Number (Person) & Distribution (\%) \\
\hline Entrepreneur & 30 & 37.5 \\
Government employees & 25 & 31.25 \\
Private employees & 15 & 18.75 \\
Student & 10 & 12.5 \\
\hline Total & 80 & 100 \\
\hline
\end{tabular}

Source: Primary Data, 2018.

Table of respondents according to the type of work above shows that the entrepreneur respondents are $37.5 \%$, civil servants are $31.25 \%$ and the rest are private employees and students at $18.75 \%$ and $12.5 \%$. This is related to the modern paradigm that highly educated people have a level of consumption of organic rice, because it is influenced by their lifestyle.

Respondents' income is very diverse, the high and low income influences lifestyle. Thus in this study the income of the respondents is grouped as in the table below.

Table 7 - Characteristics of Respondents according to Income

\begin{tabular}{ccc}
\hline Income & Number (Person) & Distribution $(\%)$ \\
\hline$\leq 1.000 .000$ & 5 & 12.5 \\
$1.000 .000-1.900 .000$ & 10 & 37.5 \\
$2.000 .000-2.900 .000$ & 35 & 18.75 \\
$\geq 3.000 .000$ & 30 & 31.25 \\
\hline Total & 80 & 100
\end{tabular}

Source: Primary Data, 2018. 
The table above shows that respondents who earn less than 1 million as many as 10 people, 1 - 1.9 million as many as 30 people, 2 - 2.9 million as many as 35 people and those with income above 3 million as many as 30 people. In this case not only high-income people who want to buy organic rice, but who only middle income also want to buy organic rice for health and environmental reasons. While the level of consumption of respondents to organic rice in one month in one high-low family is influenced by lifestyle, and awareness of health and environment and the number of family members. According to research Stobelaaret al, 2006 the majority of organic rice consumers have a high income in their sample having an average monthly income of less than $30,000.00 \mathrm{KRR}$ (147 LKR $=1 \mathrm{USD})$. Organic rice which circulating in the market there are several kinds of certain brands, while the brands are as follows in the table.

Table 8 - Characteristics of Respondents according to Organic Rice Brands

\begin{tabular}{ccc}
\hline Organic Rice Brand & Number (Person) & Distribution (\%) \\
\hline Riceya & 25 & 31.25 \\
N 790 & 25 & 31.25 \\
Coklat organic & 5 & 6.25 \\
Pandan Wangi & 15 & 18.75 \\
Mentik Wangi Delangu & 10 & 12.5 \\
\hline Total & 80 & 100 \\
\hline
\end{tabular}

Source: Primary Data, 2018.

Based on the table organic rice brand above, the most sought after by consumers is organic rice of the riceya brand and the N790 brand which each respondent is $25 \%$ and $25 \%$. For brands of Coklat organic is 5\%, Pandan Wangi is 15\% and Mentik Wangi Delangu is $10 \%$. It turns out that high prices are not a barrier for consumers to buy organic rice. While in the study of Nie et al 2018, revealed that consumers give high value to branded organic rice that have government certification. As for some reasons consumers to consume organic rice can be seen in the following table.

Table 9 - Characteristics of Respondents According to the Reason to Consume Organic Rice

\begin{tabular}{ccc}
\hline Reason to consume & Number (Person) & Distribution (\%) \\
\hline Lifestyle & 20 & 25 \\
Health & 25 & 31.25 \\
Environment & 25 & 31.25 \\
Rice Flavor and Texture & 10 & 12.5 \\
\hline Total & 80 & 100 \\
\hline
\end{tabular}

Source: Primary Data, 2018.

Based on the above table, the reason of the respondent to consume organic rice is due to the lifestyle is $25 \%$, because the health is $31.25 \%$, because the environmentally friendly is $31.25 \%$, because the taste and texture of organic rice is $12.5 \%$. Thus the reasons for consumers to consume organic rice tend to lead to health and the environment. Because they know that organic rice is processed in an organic way, without preservatives, without dye or other chemical ingredients, resulting in rice with a pulsating texture and an appetizing fragrance. The study of Becke et al 2015, also shows health benefits as the main motive for buying organic food, with concern for the environment and taste mentioned as a secondary reason, our research found that environmental problems are the main factors that influence whether to buy organic or not.

Willingness to Pay. Respondents of this study amounted to 80 people. As many as 72 people $(90 \%)$ said they were willing to pay higher than the current price to obtain organic rice products. This is because respondents are aware of the health and a healthy environment so they prefer to consume organic rice. From the study of Lavanya, B., \& Saraswathi, S. 2018, it can be concluded that consumers have a positive perception towards the usage of the 
organic products. The main reasons for choosing the organic products are concern for health and environment, while the remaining 8 people $(10 \%)$ are not willing to pay for this quality improvement. The main reason for respondents not providing to pay more is that the current price is high and the respondent is not someone who must always consume organic rice food products.

Table 10 - Willingness to Pay Consumers

\begin{tabular}{ccc}
\hline Willingness to Pay & Number (Person) & Distribution (\%) \\
\hline Ready & 72 & 90 \\
Not Available & 8 & 10 \\
\hline Total & 80 & 100 \\
\hline
\end{tabular}

Source: Research Primary Data, 2017.

As many as eight respondents who were not willing to pay consisted of several reasons; the distribution of reasons for respondents' unwillingness to pay can be seen in Table 11.

Table 11 - Unwillingness to Pay Consumers

\begin{tabular}{ccc}
\hline Unwillingness to Pay & Number (Person) & Distribution (\%) \\
\hline Feel satisfied with non-organic rice & 5 & 62.5 \\
Cannot afford 5 & 3 & 37.5 \\
\hline Total & 8 & 100
\end{tabular}

Source: Primary Research Data, 2017.

Respondents stated that not being able to pay for the price increase due to quality improvement, and the non-organic rice purchased is now able to satisfy their current physical needs, so there is no need to increase their purchasing power on products considered as similar products. Based on the percentage of price increases that respondents are willing to pay can be seen in the following table.

Table 12 - Maximum average of WTP

\begin{tabular}{ccc}
\hline Organic Rice Brand & Price (IDR/Kg) & Average WTP (IDR) \\
\hline Riceya & 25.000 & 28.494 \\
N 790 & 20.000 & 22.358 \\
Coklat organic & 17.000 & 19.358 \\
Pandan Wangi & 17.000 & 18.970 \\
Mentik Wangi Delangu & 20.000 & 21970 \\
\hline
\end{tabular}

Source: Primary Research Data, 2017.

Based on Table 12 it can be seen that the maximum average value of WTP is different for each organic rice brand depending on the price and willingness of the consumers to pay higher. The riceya organic rice brand has the highest maximum average value among other organic rice brands, which is 28.494 IDR. This is consistent with the opinion of Krystallis and Chryssohoidis (2005) which states that the maximum value that consumers are willing to spend depends on the type and price of the food product itself.

The respondent's WTP curve is formed using the cumulative amount of the number of individuals who choose a WTP value. The relationship of the curve illustrates the level of PAP that is willing to be paid by the number of respondents who are willing to pay at the level of the PAP. The WTP curve per organic rice brand is presented in Figure 1. 


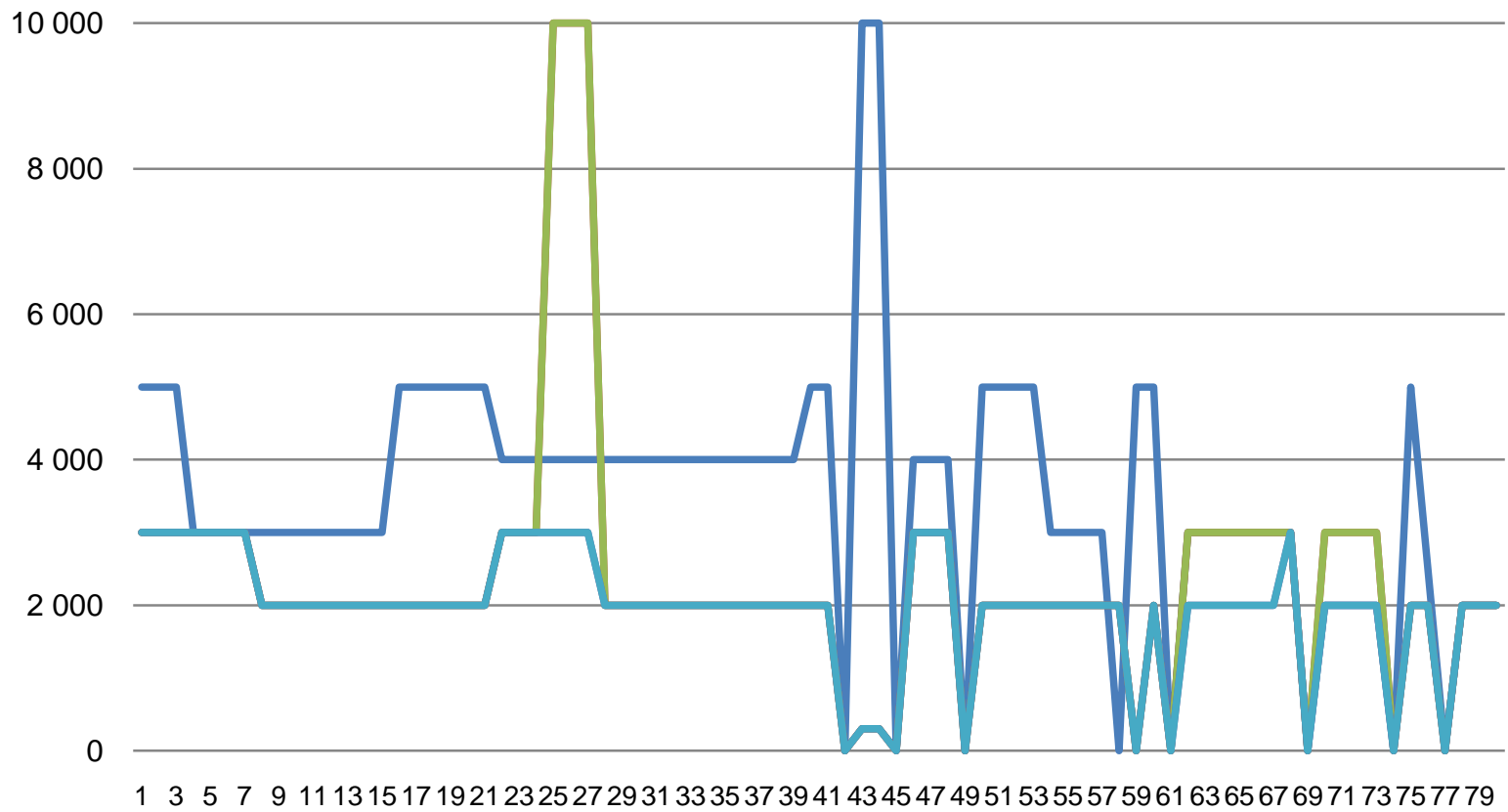

Respondent

-Riceya $\longrightarrow$ N790 Coklat Organic $\longrightarrow$ Pandan Wangi $\longrightarrow$ Mentik Wangi Delangu

Figure 1 - Curve of WTP of Organic Rice

This relationship curve is to describe the level of PAP that is willing to be paid by the number of respondents who are willing to pay at the WTP level. The WTP curve in this study has a negative slope, the higher the WTP value; the fewer people are willing to pay.

\section{CONCLUSION}

Organic rice which circulating in the city of malang there are some brands such as the brand of riceya, $\mathrm{N} 790$, coklat organik, pandan wangi and mentik wangi delangu. Characteristics of consumers of organic rice are mostly women/female; the average is married and is in the age range of 30-39 years. Consumer characteristics mostly work as self-employed and civil servants (PNS), earning an average of over three million as well as with an average Bachelor's degree of the last education. Consumers want to pay more to obtain or buy organic rice for the health and environmental reasons. The maximum average value of WTP for each kilogram of organic rice with the riceya brand is 28.494 IDR; brand of N790 is 22.35 IDR; coklat organic brand is 19.358 IDR; pandanwangi brand equal to 18.970 IDR; and mentik wangi delangu brand is 21.790 IDR.

\section{ACKNOWLEDGEMENTS}

The authors would like to thank LPDP (Indonesia Endowment Fund for Education) for their support to this paper.

\section{REFERENCES}

1. Akhmad Fauzi, P. (2006). Ekonomi Sumber Daya Alam and Lingkungan Teoridan Aplikasi. Jakarta: PT Gramedia Pustakan Utama. 
2. Hanley H, Spash CL. 1995. Cost-Benefit Analysis and Environment.

3. Balogh, P., Békési, D., Gorton, M., Popp, J., \& Lengyel, P. (2016). Consumer willingness to pay for traditional food products. Food Policy, 61, 176-184.

4. Becker, N., Tavor, T., Friedler, L., \& Bar, P. (2015). Two stages decision process toward organic food: The case of organic tomatoes in Israel. Agroecology and Sustainable Food Systems, 39(3), 342-361.

5. Castro, L. M., Calvas, B., \&Knoke, T. (2015). Ecuadorian banana farms should consider organic banana with low price risks in their land-use portfolios. PloS one, 10(3), e0120384.

6. Engel, James F., Roger D. Blacwell, Paul W. Miniard. 1990. Consumer Behavior. Dyriden Press, Chicago, IL.

7. Engel, James F., Roger D. Blacwell, Paul W. Miniard. 1994. First Volume Consumer Behavior, Sixth Edition. Jakarta: BinaRupaAksara.

8. Garretson, J.A., D. Fisher, and S. Burton. 2002. "Antecedents of private label attitude and national brand promotion attitude: similarities and differences". Journal of Retailing, Vol. 78 No. 1, pp. 91-99.

9. Ginigaddara, G. A. S., Madushika, J. P. S. N., Bandara, A. M. K. R., \&Dissanayaka, S. P. (2017). Purchasing decision making and consumer preference for traditional rice in Sri Lanka: A case study in Kegalle district. International Journal of Advanced Scientific Research and Management, 2(4).

10. Hanley H, Spash CL. 1995. Cost-Benefit Analysis and Enviroment. USA (USA): Edward Elgar Publihing Company

11. Jukes, T. H., \& Anderson Stout, Z. E. (1977). Organic food. Critical Reviews in Food Science \& Nutrition, 9(4), 395-418.

12. Krystallis, A. and Chryssohoidis, G. (2005) Consumers' Willingness to Pay for Organic Food: Factors That Affect It and Variation per Organic Product Type. British Food Journal, 107, 320-343.

13. Lavanya, B., \&Saraswathi, S. (2018). Consumer Buyingbehaviour-A Study with reference to Organic Products in Hyderabad City.

14. Liang, R. D. (2016). Predicting intentions to purchase organic food: the moderating effects of organic food prices. British Food Journal, 118(1), 183-199.

15. Made Novandri SN. 2010. Analisis Pengaruh Kualitas Produk, Harga, and IklanTerhadap Keputusan Pembelian Sepeda Motor Yamaha Pada Harpindo Jaya Cabang Ngaliyan. Skripsi: FE, Undip Semarang

16. Nie, W., Abler, D., Zhu, L., Li, T., \& Lin, G. (2018). Consumer Preferences and Welfare Evaluation under Current Food Inspection Measures in China: Evidence from Real Experiment Choice of Rice Labels. Sustainability, 10(11), 4003.

17. Paci, F., Danza, A., Del Nobile, M. A., \& Conte, A. (2018). Consumer acceptance and willingness to pay for a fresh fish-burger: A choice experiment. Journal of cleaner production, 172, 3128-3137.

18. Pantoja, B. R., Badayos, G. G., \&Rola, A. C. (2016). Constraints to adoption of organic rice production in selected areas in the Philippines. Rice-Based Biosystems Journal, 2(1), 34-43.

19. Peter, J. P., Olson, J. C., \&Grunert, K. G. (1999). Consumer behaviour and marketing strategy (pp. 329-48). London: McGraw-Hill.

20. Shin, Y. H., Moon, H., Jung, S. E., \&Severt, K. (2017). The effect of environmental values and attitudes on consumer willingness to pay more for organic menus: A value-attitudebehavior approach. Journal of Hospitality and Tourism Management, 33, 113-121.

21. Simanjuntak, G. E. M. S., 2009."Analisis Willingness to Pay (WTP) Masyarakat terhadap Peningkatan Pelayanan Sistem Penyediaan Air Bersihdengan WSLIC (Water Sanitation for Low Income Community)".(Studi Kasus Desa Situdaun, Kecamatan Tenjolaya, kabupaten Bogor).

22. Stobelaar, D. J., Casimir, G., Borghuis, J., Marks, I., Meijer, L. and Zebeda, S.Adolescents' attitudes towards organic food: a survey of 15 to 16-year old school children, International Journal of Consumer Studies, 31, 4: pp 349-356,(2006). 
23. Takei, N. (2019). Medical Rice: Brown Rice for Health and Low Protein Rice for Preventing CKD. EC Nutrition, 14, 7-10.

24. Verma, D. K., irti Shukla, K., Venture, A. P., Sharma, A., Ansari, M. A., Misra, K. K., ... \& Singh, S. (2011). F armers' Digest.

25. Yakin, (1997), Ekonomi Sumber Daya and Lingkungan; Teoridan Kebijaksanaan Pembangunan Berkelanjutan. Edisi I. Cetakan I. Penerbit Akademika Presindo. Jakarta 